Western North American Naturalist 70(1), (C) 2010, pp. 9-18

\title{
PEDIOMELUM RYDBERG (LEGUMINOSAE) IN ARIZONA AND TWO PREVIOUSLY UNDESCRIBED SPECIES
}

\author{
Stanley L. Welsh ${ }^{1}$ and Max Licher ${ }^{2}$
}

\begin{abstract}
Examination of specimens of Pediomelum in the Brigham Young University Stanley L. Welsh Herbarium (BRY), and others obtained on loan from the Northern Arizona University Deaver Herbarium (ASC), the Arizona State University Herbarium (ASU), and the University of Arizona Herbarium (ARIZ), allows for substantial reevaluations of the species in Arizona and for description of 2 previously undescribed species. Pediomelum verdiensis S.L. Welsh and M. Licher is described as a new species from substrate derived from the Tertiary Verde Formation, Verde Valley, north central Arizona. Pediomelum pauperitense S.L. Welsh, M. Licher, and N.D. Atwood is described as a new species from outcrops of Paleozoic limestone near Poverty Mountain, Coconino County, Arizona, north of the Grand Canyon. For the species of Pediomelum in Arizona, we include a summary revision, a key to the taxa, and a list of specimens examined for study.
\end{abstract}

Key words: Pediomelum, new taxa, summary revision, Arizona flora.

The genus Pediomelum was erected by P.A. Rydberg (1919) to accommodate those plants from North America previously known under the collective heading Psoralea L. (Linnaeus 1753). The type material for Psoralea came from Africa; and in a strict sense, Psoralea consists of a dozen or more species of South African shrubs or small trees. Their relationship to North American materials has been discounted not only by Rydberg but also by other workers in the Leguminosae, tribe Psoraleae (Barneby 1989, Isely 1998, Welsh et al. 2008).

Attention to species of Pediomelum Rydberg in Arizona was stimulated when photos and specimens of 2 distinctive acaulescent to short-caulescent species of the genus were received from coauthor Max Licher. The plants differ markedly from each other in floral characteristics. One is large-flowered (11-15 mm) with white banners and with most calyx tubes exceeding $6 \mathrm{~mm}$, the length indicated by Grimes (1990) for Pediomelum megalanthum. Specimens of that species from throughout its range had calyx tube lengths of 5.0-6.5 mm. The other plant sent by Licher had smaller flowers (9.8) 10-11.3 mm with blue-purple or purple banners and calyx tubes (3) $3.5-4.8 \mathrm{~mm}$ in length. Identification of both the large- and small-flowered plant specimens was attempted following Grimes (1990). The larger, white-bannered plants clearly fit within the concept of
P. megalanthum. The smaller, purple-bannered plants clearly do not fit within that concept.

Grimes (1990), in his summary monograph of New World Psoraleae, limits the concept of P. megalanthum, sensu lato-including vars. megalanthum, retrorsum, and epipsilum (herein treated at specific rank) - to those materials having the calyx tube at least 6 (actually $5-6.5$ ) $\mathrm{mm}$ long and upper calyx teeth lanceolate. He included among the species having calyx tubes shorter than $6 \mathrm{~mm}(2-4.5 \mathrm{~mm})$, the geographically disjunct $P$. pariense (S.L. Welsh \& N.D. Atwood) Grimes and P. californicum (S. Watson) Rydberg, and the Arizona species $P$. mephiticum (S. Watson) Rydberg. The first of these, $P$. pariense, occurs mainly on Tertiary Claron and Jurassic Carmel limestone formations in central to western Kane County, Utah; P. californicum is known from southern California and northern Baja California, Mexico; and P. mephiticum is known mainly from northern Mohave County, Arizona, north of the Grand Canyon, and from southwestern Washington County, Utah. Pediomelum mephiticum extends south of the Grand Canyon to the vicinity of Wikieup, Arizona.

\section{Methods}

A list of specimens from Arizona that we examined and cite appears in the Appendix. 


\section{Distribution of Pediomelum species in Arizona}

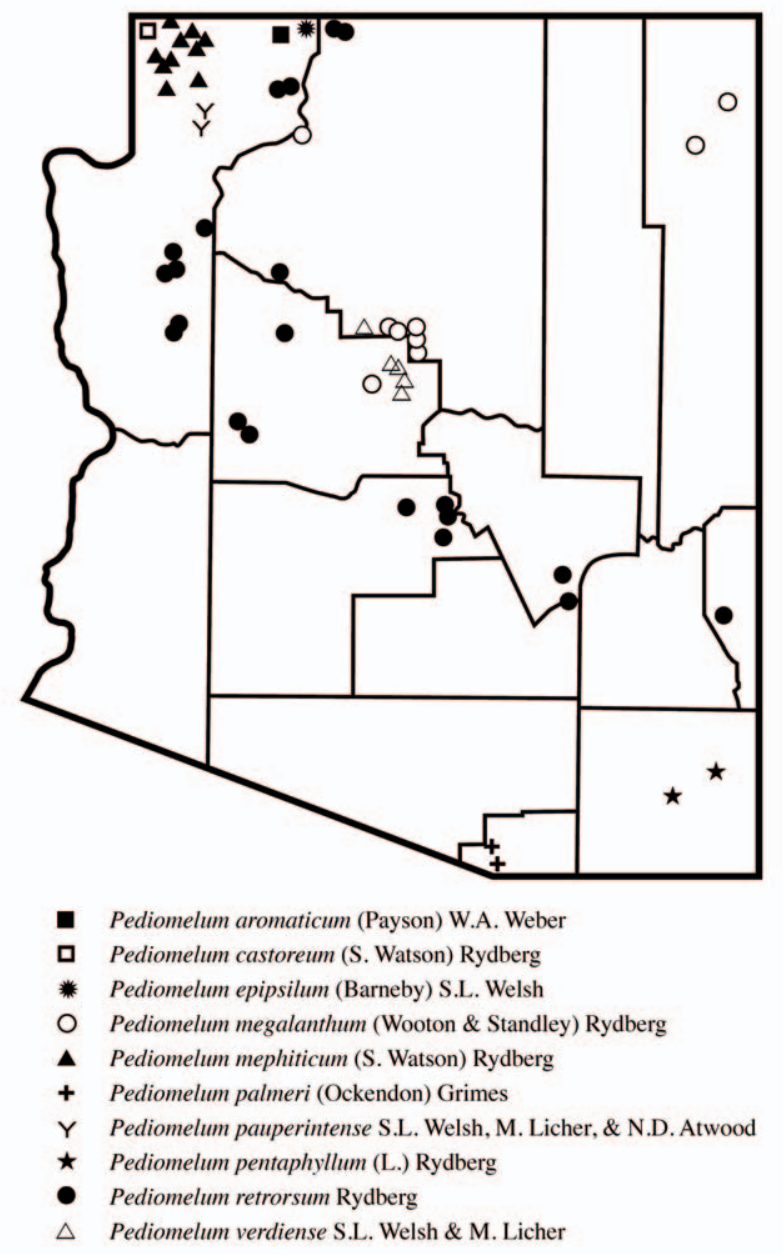

Fig. 1. Distribution map of Arizona species of Pediomelum.

This study is based not only on specimens of Pediomelum at the Brigham Young University Stanley L. Welsh Herbarium (BRY) but also on others obtained on loan from the Northern Arizona University Deaver Herbarium (ASC), the Arizona State University Herbarium (ASU), and the University of Arizona Herbarium (ARIZ). The majority of sheets examined of $P$. epipsilum (Barneby) S.L. Welsh were from Utah; only 2 were from Arizona, both on the Triassic Moenkopi Formation west of Fredonia. Specimens from throughout the distribution of $P$. megalanthum were examined, but only those from Arizona and New Mexico are cited. Those of $P$. retrorsum Rydberg were examined also, the majority of which were from
Arizona. Three sheets of the acaulescent $P$. pentaphyllum (L.) Grimes were examined, all from Greenlee and adjacent Cochise counties, Arizona; and one sheet was examined of the short-caulescent P. palmeri (Ockendon) Grimes from Santa Cruz County, Arizona. Specimens from throughout Arizona (all from populations adjacent to the Nevada border in Mohave County) and Nevada were examined for P. castoreum (S. Watson) Rydberg.

\section{Results}

Review of specimens examined for this study confirmed the presence of 10 species of Pediomelum in Arizona. Examination also 
confirmed the distinct nature of the small-flowered materials with ascending hairs on pedicels and peduncles from the Verde Limestone Formation. This examination also demonstrated the existence of a second set of small-flowered plants with ascending hairs on both pedicels and peduncles from north of the Grand Canyon in the vicinity of Poverty Mountain. The specimens from the Verde Limestone Formation apparently bear flowers with all petals more or less suffused with dark purple or blue-purple. Those from the Poverty Mountain area are pale-flowered and the leaves tend to greatly overtop the inflorescences. Both the Verde Limestone and the Poverty Mountain plants are described and named below. N.D. Atwood provided insight into habitat and growth of the novelty described below from the vicinity of Poverty Mountain in northern Arizona. He is thoroughly familiar with the plant in its habitat and has collected it previously.

Species of the genus Pediomelum, as they occur in Arizona, are mainly geographically discrete from each other; that is, the distributions still occupy discrete habitats within areas of apparent overlap (Fig. 1).

\section{TAXONOMY}

The following key will serve to delimit the species of Pediomelum that are known to occur in Arizona:

1. Leaflets conspicuously bicolored, cinereous beneath, bright green and glabrous to glabrate above (except along some veins); plants only known from the Triassic Moenkopi Formation from SW Kane Co., Utah, and N Coconino Co., Arizona......... P. epipsilum (Barneby) S.L. Welsh

- Leaflets mainly greenish on both sides, or if contrasting, pale beneath and green above, the upper surface also strigose to pilose.......... 2

2. Plants definitely caulescent; leaflets green on both sides; flowers mainly $<10 \mathrm{~mm}$ long. . . . . . . 3

- Plants acaulescent or short-caulescent; leaflets typically pale beneath; flowers mostly $>10$ $\mathrm{mm}$ long; plants variously distributed ........ 4

3. Leaves palmately compound; plants erect or ascending, known from the Chinle Formation, SE Washington Co., Utah, and N Mohave Co., Arizona ..... . . P. aromaticum (Payson) W.A. Weber

- Leaves with terminal leaflet petiolulate (the petiolule 5-10 $\mathrm{mm}$ long); plants decumbent or prostrate, Santa Cruz Co., Arizona. . . . . . . . . ............... P. palmeri (Ockendon) Grimes
4. Calyx lobes very unequal, the lower one much enlarged or much differing in shape from the narrowly subulate upper ones; seeds reticulate or rugose .......................... 5

- Calyx lobes subequal to moderately unequal, the lower one not-much enlarged; seeds smooth ........................6 6

5. Calyx tube 3-4 mm long; lower calyx lobe rounded or obtuse at the apex, ca. $10 \mathrm{~mm}$ long; plant known from NW Mohave Co., Arizona, Clark Co., Nevada, and San Bernardino Co., California, often growing in sand.......... ............. P. castoreum (S. Watson) Rydberg

- Calyx tube 4-5 mm long; lower calyx lobe acute to attenuate at apex, ca. $12-15 \mathrm{~mm}$ long; plants known from Cochise Co., Arizona, adjacent New Mexico and Mexico .......... ................ P. pentaphyllum (L.) Grimes

6. Calyx tube mainly $5.0-6.5 \mathrm{~mm}$ long; flowers $11-15 \mathrm{~mm}$ long $\ldots \ldots \ldots \ldots \ldots \ldots \ldots \ldots \ldots$

- Calyx tube mainly $2.5-4.5 \mathrm{~mm}$ long; flowers 7.3-13.5 mm long; plants of north central Arizona and $\mathrm{SW}$ Utah. ................. 8

7. Petioles and peduncles with hairs appressed or appressed ascending, sometimes with a few long spreading hairs; plants of Apache Co. and disjunct in S Coconino and adjacent Yavapai cos., Arizona, NW New Mexico, W Colorado, and E Utah. ...................... .... P. megalanthum (Wooton \& Standley) Rydberg

- Petioles and peduncles with retrorse or retrorsespreading hairs; plants of Coconino, Graham, Gila, Maricopa, Mohave, and Yavapai cos., Arizona, Clark, Lincoln, and Nye cos., Nevada, and Washington Co., Utah ... P. retrorsum Rydberg

8. Petioles and peduncles both retrorsely hairy; lateral and upper calyx teeth narrowly subulate to narrowly elliptic; plants of various substrates in N Mohave Co., Arizona, N of Grand Canyon, extending S to Wickiup, and Washington Co., Utah. ................. . ........... . . mephiticum (S. Watson) Rydberg

- Petioles with hairs appressed ascending or ascending; peduncles ascending- to spreadinghairy; lateral and upper calyx teeth lance-elliptic to lance-subulate or narrowly oblanceolate to oblong-attenuate .......................9

9. Pedicels 3-3.5 (5) mm long; bracts 5-8 mm long; seed 4.2-4.8 mm long; flowers (9.8) $10-11.3$ $\mathrm{mm}$ long, banner purple or suffused with purple, not strongly contrasting with wings and keel; plants known from Tertiary Verde Limestone Formation in Yavapai Co., Arizona ..... . . . . . . . . . P. verdiense S.L. Welsh \& M. Licher

- Pedicels 1.5-2.5 (3) mm long; bracts 3-5 mm long; seed $3.8 \mathrm{~mm}$ long; flowers 7.3-10 (10.2) $\mathrm{mm}$ long, banner white or cream, wings of similar color, both contrasting with purple keel; 
plants known from Paleozoic limestone, vicinity of Poverty Mountain, Mohave Co., Arizona P. pauperitense S.L. Welsh, M. Licher, \& N.D. Atwood

Grimes (1990) revised the genus Pediomelum as part of a large, very complex work. Under discussion of $P$. megalanthum var. megalanthum, he noted (p. 82):

Some plants in populations of var. megalanthum commonly are canescent. This is particularly true of those populations disjunct in Yavapai County, Arizona. In one collection from Yavapai County, (Harbison, 9 June 1941, DS), the floral measurements fall within the range of Pediomelum mephiticum, but the peduncular pubescence is that of var. megalanthum. As P. mephiticum is not otherwise known to occur in Yavapai County, and as there are adjacent populations whose flower sizes fit nicely into megalanthum, I take this specimen to be an aberrant variant of the latter.

A duplicate of the Harbison collection is at ARIZ and is herein described and long known as $P$. verdiense. Specimens from near the locality known for $P$. verdiense, in adjacent Coconino County (vicinity of or actually within Sedona), are clearly $P$. megalanthum, sensu lato, and are disjunct from the remainder of that species' distribution by more than $100 \mathrm{~km}$. However, pubescence of stems (appressed or ascending) and peduncles (spreading) is hardly characteristic of $P$. megalanthum as a whole, as it occurs from northeastern Arizona and northwestern New Mexico northward in the Colorado drainage system of western Colorado and eastern Utah. Possibly this disjunct material, herein still included in $P$. megalanthum, also deserves taxonomic consideration, but that question is beyond the scope of this paper. Two specimens of $P$. megalanthum from near Sedona are present at BRY; they are C.F. Deaver 6197, 5 May 1963, and M. Licher 1915, 19 Apr 2008. The former bears the annotation by Grimes as $P$. megalanthum var. retrorsum (though the hairs are not retrorse). They are both reinterpreted herein as $P$. megalanthum sensu lato and are clearly distinct, as noted in the key above, from $P$. verdiense. Specimens of $P$. retrorsum examined in the herbaria cited above are from Coconino, Gila, Graham, Greenlee, Maricopa, Mohave, and Yavapai counties; all are easily distinguished by their larger calyx tubes (generally exceeding $5 \mathrm{~mm}$ ) and retrorsely hairy peduncles and petioles. The same morphology holds true for specimens of $P$. retrorsum at BRY from Clark, Lincoln, and Nye counties, Nevada, and Washington County, Utah.

Calyces enlarge somewhat as the fruit matures, but the enlargement mainly involves lateral expansion of the tube and teeth or lobes, not the elongation of them. Thus, the widest measurements of the lobes noted in the descriptions below are for calyces of fruiting specimens.

Specimens from the Verde Formation in Yavapai County, Arizona, were compared with specimens of $P$. mephiticum from Mohave County, Arizona; Washington County, Utah; and Clark County, Nevada, in the herbarium at BRY. The Verde Formation specimens are morphologically distinct from $P$. mephiticum and are $>100 \mathrm{~km}$ from the nearest known locality of that species.

Two previously undescribed species are named and described below.

\section{Pediomelum verdiensis S.L. Welsh \& M. Licher sp. nov.}

Similis $P$. mephiticum sed in pubescentiis ascendentibus caulium floribus plerumque majoribus et vexillis purpurascentibus et pubescentibus densioribus interalia differt.

TyPe.-USA, Arizona, Yavapai Co., wash just north of Middle Verde exit from I-17, on flats above wash, locally frequent, $34^{\circ} 37^{\prime} 05^{\prime \prime} \mathrm{N}$, $111^{\circ} 51^{\prime} 43.0^{\prime \prime} \mathrm{W}, 3445 \mathrm{ft}$ (ca. $1050 \mathrm{~m}$ ), desert scrub with widely scattered junipers, Verde Formation limestone soils, M. Licher 1911, 18 April 2008, holotype BRY, isotype ASC.

\section{Verde Breadroot}

Acaulescent to short caulescent, 4.5-9 (15) $\mathrm{cm}$ tall, from slender, subterranean caudex branches arising from deep-seated ellipsoid to narrowly tapering tuberous roots; aboveground stems lacking or with very short internodes and more or less obscured by leaf bases and stipules, less commonly with internodes elongated (pseudo-peduncles) 0.5-6.5 cm long, spreading white-hairy; leaves (3) 5-foliolate; petioles 2-7.5 (10) cm long, with hairs appressed-ascending; 


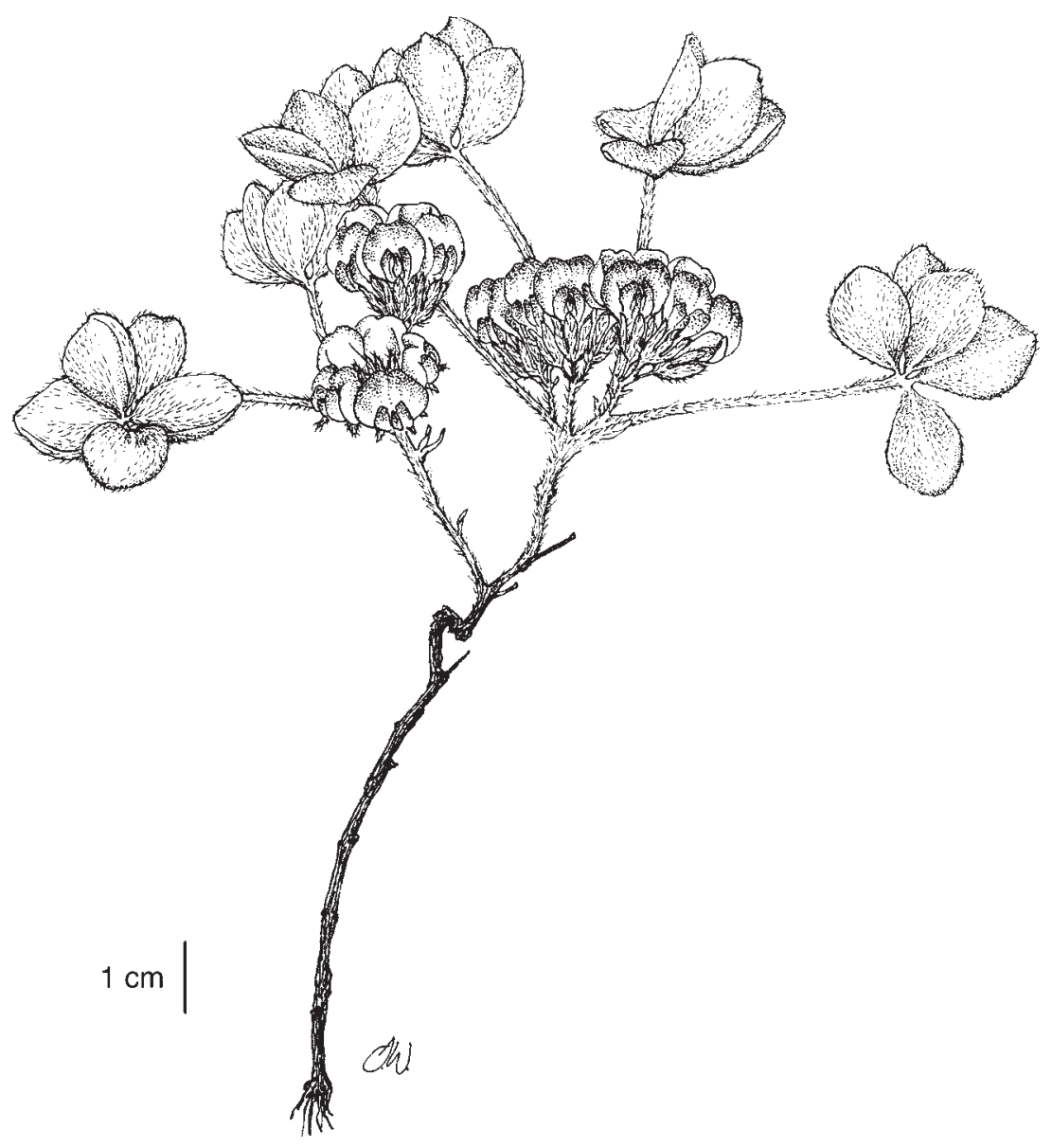

Fig. 2. Illustration of Pediomelum verdiense sp. nov., voucher M. Licher 2015, 28 May 2008 (BRY).

leaflets 8-23.5 mm long, 7-16.5 mm wide, obovate to broadly so, gray green, densely strigose, and obscurely punctate beneath; green to yellow green, thinly strigose overall (more densely canescent along veins above and on the lower surface), obviously punctate above; stipules scarious, 4-16 mm long, connate and without leaf otherwise on lowermost nodes of caudex, adnate to petiole base and bilobed on foliage leaves above, the upper ones densely white strigose; peduncles $0.5-2$ (6) $\mathrm{cm}$ long, spreading or spreading-ascending white-hairy; inflorescences (cymose) with branches mainly 5-7-flowered, $1.5-2.5 \mathrm{~cm}$ long; pedicels 3-3.5 (5) $\mathrm{mm}$ long, filiform; bracts elliptic, 5-8 $\mathrm{mm}$ long; flowers (9.8) $10-11.3 \mathrm{~mm}$ long, the banner purple or suffused with pale purple, the wings and keel dark purple; calyx (9) 10-11 mm long (11.7 mm in fruit), the tube (3) $3.5-4.8 \mathrm{~mm}$ long (from end of strongly gibbous-saccate base to the sinus between the 2 lateral teeth), the lower tooth elliptic, (4.5) 6.0-8.2 (9.2 in fruit) mm long and $2.0-3.5 \mathrm{~mm}$ wide, the upper teeth lance-elliptic to lance-subulate or oblanceolate, 4.2-6.5 (7.3) mm long and $1.5-2.3 \mathrm{~mm}$ wide; pods included in the calyx; seed 4.2-4.8 $\mathrm{mm} \times 2.8-3 \mathrm{~mm}$, gray brown with purple mottling (Fig. 2).

Paratypes.-Arizona, Yavapai Co., Camp Verde, Chas. F. Harbison 41.312, 9 Jun 1941 ARIZ! - sandy ridges, Perkinsville, Paulden, $4350 \mathrm{ft}, 5-7-1961$, D. Demaree 43936, ASC!, ARIZ! - S of junction of U.S. I-17 and Arizona Hwy. 199, on dirt road leading to Arizona 260, roadside, Wojciechowski \& Sanderson 212, 23 Apr 1992, ARIZ! - low-angle south-facing 


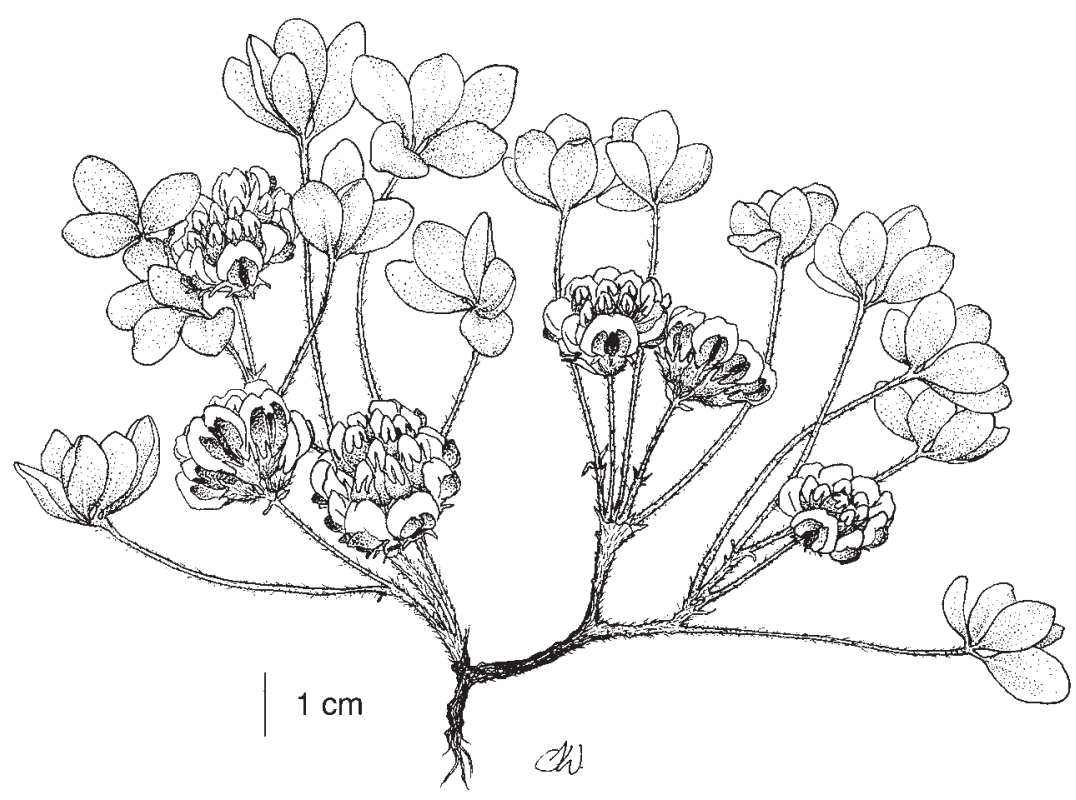

Fig. 3. Illustration of Pediomelum pauperitense sp. nov., voucher Salywon et al. 1107, 21 May 2001 (BRY).

slope of Verde Formation, west of where Trail 521 starts, near Campe Verde, $3200 \mathrm{ft}$, Rink \& Murov 1840, 25 Apr 2003, ASC! - Verde Valley $3.1 \mathrm{mi} \mathrm{E}$ of Verde River on the road between Campe Verde and Payson. White limestone hills of the Verde Formation, Anderson 89-43, 7 May 1989, ASU! - ca. 300 yards E of I-17, off Exit 298 (Montezuma Castle National Monument exit), $34^{\circ} 36.843^{\prime} \mathrm{N}, 111^{\circ} 51.548^{\prime} \mathrm{W}$, $3623 \mathrm{ft}$ (1100 m), whitish limestone soil, Hodgson 10937, 30 May 1998, ASU!

Sonoran Desert scrub and scattered juniper communities on Tertiary (Miocene-Pliocene) Verde limestone or compacted roadsides at ca. $1050 \mathrm{~m}$, in Yavapai Co., Arizona.

"Flat-topped, grayish-white hills in the center of the Verde Valley are chalky lake limestone and siltstone deposited when the Verde River was dammed at its southeast end by uplift of the Central Highlands" (Chronic 1983). "The chalk-like limestone layers are interlayered with pink silt and sand brought in by streams, and with volcanic ash from long-continued vulcanism in this region" (loc.cit., 191) Deposition of the limestone was evidently from lime-rich waters draining from Paleozoic limestones of the Colorado Plateau (Chronic
1983), which preserve the remains of horses and mastodons as well as snails and clams "of the same species that live in fresh water streams and lakes today" (Nations and Stump 1981, p. 54). The Verde Formation is estimated to be 1.8-10 million years old.

The more-ancient lacustrine limestones in Utah and the White and Pink limestones of the early Tertiary Claron Formation serve as substrates for a series of local endemics (including P. pariense, which is not known from Arizona). It is hardly surprising that such endemics might occur in similar substrates in Arizona.

\section{Pediomelum pauperitense S.L. Welsh, M. Licher, \& N.D. Atwood sp. nov.}

Similis $P$. verdiensem in pubescentiis ascendentibus caulium sed in vexillo et alis albis (nec purpureis) et floribus foliorum plus superantibus differt.

TyPe.-USA, Arizona, Mohave Co., T35N, R12W, Sec. 35/36, SW of Poverty Mountain, near Dewdrop Spring; 1756 m, in gravelly limestone soil in pinyon-juniper community, L.C. Higgins 23135, 25 May 2001, holotype BRY, isotypes distributed previously as P. mephiticum. 
Poverty Mountain Breadroot

Acaulescent to short caulescent, 10-15 cm tall, from slender, subterranean caudex branches arising from deep-seated tuberous roots; stems above ground lacking or with very short internodes and more or less obscured by leaf bases and stipules, less commonly with internodes elongated (pseudo-peduncles) 0.5-2.5 (5) cm long, spreading white-hairy; leaves 5-foliolate; petioles $2-11.5 \mathrm{~cm}$ long, much surpassing the inflorescences, with hairs appressed-ascending; leaflets 8-28 mm long, 4-22 mm wide, obovate to broadly so, gray green, densely strigose, and obscurely punctate beneath; green to yellow green, thinly strigose overall above (more densely canescent along veins above and on the lower surface), and obviously punctate above; stipules scarious, 4-16 mm long, connate, adnate to petiole base and bilobed on foliage leaves above, the upper ones densely white strigose; peduncles $0.5-4.5 \mathrm{~cm}$ long, ascending or spreading-ascending white-hairy and with longer spreading white hairs; inflorescences (cymose) with branches mainly 3-7flowered, 1.5-2.5 cm long; pedicels 1.5-2.5 (3) $\mathrm{mm}$ long, filiform; bracts elliptic, 3-5 mm long; flowers 7.3-10 (10.2) mm long, the banner white or cream, the wings pale, the keel dark purple; calyx (7) 7.3-9.6 mm long, the tube (2.5) 3-3.7 $\mathrm{mm}$ long (from end of strongly gibbous-saccate base to the sinus between the 2 lateral teeth), the lower tooth elliptic, (4) 5-6.0 $\mathrm{mm}$ long and 1.4-2.5 mm wide, the upper teeth lanceolate to oblong and attenuate to acute, $4.2-6.5 \mathrm{~mm}, 0.9-1.5$ (2.5 in fruit) $\mathrm{mm}$ wide; pods included in the calyx, transversely ruptured; seed $3.8 \times 2.5 \mathrm{~mm}$, olive to gray brown (Fig. 3).

Paratypes.-Arizona, Mohave Co., T34N, R11W, Sec. 4, SE of Poverty Mountain, Arizona Strip, SW of Mt. Trumbull, $5500 \mathrm{ft}$, Atwood \& Franklin 18901, 16 May 1993, BRY! - T35N, R12W, Sec. 35-36, SW of Poverty Mountain, near Dewdrop Spring, $1756 \mathrm{~m}$, gravelly limestone, pinyon-juniper community, Higgins 23135, 25 May 2001, holotype BRY! T35N, R12W, Sec. 35-36, SE of Poverty
Mountain, $1650 \mathrm{~m}$, gravelly soil, pinyonjuniper community, Higgins 23137, 25 May 2001, holotype BRY! - BLM road, S of Poverty Mountain and SW of Salt Spring, T34N, R11W, 5000-5500 ft, Salywon et al. 1107, 21 May 2001, BRY!

\section{ACKNOWLEDGMENTS}

We wish to acknowledge the curators of the herbaria in Arizona for loaning specimens, especially those at Northern Arizona University at Flagstaff (ASC), Arizona State University at Tempe (ASU), and University of Arizona at Tucson (ARIZ). Acknowledged also for their help with this paper are graphics expert Randy Baker, who provided the illustrations of the 2 new taxa, and Shannie Workman.

\section{Literature Cited}

Barneby, R.C. 1989. Psoralidium Rydberg; Pediomelum Rydberg. Pages 20-27 in R.C. Barneby, author, Fabales. Intermountain flora: vascular plants of the Intermountain West, U.S.A. edited by A. Cronquist, A.H. Holmgren, N.H. Holmgren, J.L. Reveal, and P.K. Holmgren. Volume 3B. New York Botanical Garden, Bronx, New York, NY.

Chronic, H. 1983. Roadside geology of Arizona. Mountain Press Publishing Company, Missoula, MT. 321 pp.

Grimes, J.W. 1990. A revision of the New World species of Psoraleae (Leguminosae: Papilionoideae). Memoirs of the New York Botanical Garden 61:56-89.

IsELY, D. 1998. Native and naturalized Leguminosae (Fabaceae) of the United States, exclusive of Alaska and Hawaii. Brigham Young University, Provo, UT. 1007 pp.

Linnaeus, C. 1753. Species Plantarum. Holmiae, Impensis Laurentii Salvii. 2 volumes ([xii], 560, [ii], 561-1200, [31] pp.).

Nations, D., AND E. Stump. 1981. Geology of Arizona. Kendall/Hunt Publishing Company, Dubuque, IA. $221 \mathrm{pp}$.

Rydberg, P.A. 1919. Pediomelum Rydberg. Pages 17-24 in North American Flora 24(1): Family 24. Fabaceae. Tribe 6. Psoraleae. 64 pp.

Welsh, S.L., N.D. ATwood, S. GoOdRICh, AND L.C. HigGINS. 2008. A Utah flora. 4th edition. M.E. Jones Endowment Fund, Monte L. Bean Life Science Museum, Brigham Young University, Provo, UT. $1057 \mathrm{pp}$.

Received 31 March 2009 Accepted 22 September 2009

Appendix follows on pages 16-18. 
APPEndix. Pediomelum specimen citations.

Pediomelum aromaticum (Payson) W.A. Weber

ArIzona: Mohave Co.-T40N, R5W, S5, Clay Basin, ca. $1.5 \mathrm{mi} \mathrm{SE}$ of Lone Butte and $\mathrm{E}$ of the Kane Beds, elevation 1500 m, Atwood 18120A, 13 Jun 1993, ASU!, BRY!, ARIZ! - T40N, R6W, Sec. 12, Chinle clay soils, Cedar Ridge, 1550 m, Higgins 26666, 25 May 2005, BRY!

Pediomelum castoreum (S. Watson) Rydberg

Arizona: Mohave Co.-Beaverdam, $1750 \mathrm{ft}$, Kearney d Peebles 13206, 17 Apr 1937, ARIZ! - Beaverdam, $2000 \mathrm{ft}$, Peebles \& Parker 14770, 9 May 1940, ARIZ! - Beaver Dam, T40N, R15W, Sec. 4, Gierisch 4346, 25 May 1978, ASC!, ARIZ!, ASU!, BRY! - Littlefield exit on I-15, ca. $2400 \mathrm{ft}$, E. Neese 12948, 13 Apr 1983, BRY! - T41N, R16W, Sec. 11, $2350 \mathrm{ft}$, sandy area atop bluffs, ca. $2 \mathrm{mi} \mathrm{S}$ of state line, W side Beaver Dam Wash, Baird 2225, 3 Apr 1986, BRY! - T41N, R16W, ca. 5 mi NW of Littlefield, up Beaver Dam Wash, $2140 \mathrm{ft}$, Atwood \& Thorne 12016, 17 Apr 1986, BRY! - T41N, R16W, Sec. 2, Beaver Dam Wash, mesa top, E side of wash across from Welcome Creek, red sand dunes, $2372 \mathrm{ft}$, Thorne, Atwood, \& Baird 4465, 17 Apr 1986, BRY! - Grand Canyon Parashant National Monument, 2 mi due SSE of Tassi Spring, sandy soil, $600 \mathrm{~m}$, Atwood \& Madsen 26607, 29 Mar 2001, BRY! - Gravelly (limestone) wash bottom, $500 \mathrm{~m}$, Tassi Wash, Grand Wash vicinity, T33N, R15W, Sec. 8, Welsh \& Atwood 28014, 14 Apr 2001, BRY!

Nevada: Clark Co.-Spreading perennial herb, locally common in sandy soils, $4.5 \mathrm{mi} \mathrm{SW}$ of the Riverside Bridge, Virgin River drainage, ca. $1500 \mathrm{ft}$, Niles, Schramm, \& Holland 1886, 21 Apr 1978, BRY! - Overton Airport road toward the Virgin River, T15S, R68E, Sec. 36?, Williams, Holland, \& Tiehm 79-20-1, 12 Apr 1979, BRY! T23S, R70E, ca. $7 \mathrm{mi} \mathrm{W}$ of Mesquite, S. \& S. Welsh 21540, 7 Apr 1983, BRY! - T31S, R71E, first Mesquite eastern I-15 exit, $1600 \mathrm{ft}$, Kass \& Neese 1521, 26 Mar 1984, BRY! - T15S, R68E, Sec. 35, common locally, in deep sand deposits south of road, east base of Mormon Mesa, Virgin Valley, $1400 \mathrm{ft}$, Niles et al. 419717 Mar 1995, BRY! Mud Hills, $0.65 \mathrm{mi}$ SE of Gold Butte Road on road to St. Thomas Gap, then $0.4 \mathrm{mi}$ to hills to northeast, $2640 \mathrm{ft}$, $36^{\circ} 24^{\prime} 49.4^{\prime \prime} \mathrm{N}, 114^{\circ} 06^{\prime} 31.7^{\prime \prime} \mathrm{W}$, Tiehm \& J. Nachlinger 14708, 27 Apr 2005, BRY!

\section{Pediomelum epipsilum (Barneby) S.L. Welsh}

Arizona: Mohave Co.-About $6 \mathrm{mi} \mathrm{W}$ of Fredonia, along Hwy 369, Higgins 11948, 29 May 1978, ASU!, BRY! - 5-6 mi W of Fredonia on Hwy. 59, clay soils, atriplexephedra-Cowania community, Higgins \& B. Welsh 13368, 26 May 1983, BRY!

UtaH: Kane Co.-Ca. $25 \mathrm{mi}$ W of Cockscomb, along Hwy. 89, growing with eriogonum, sagebrush, and juniper, T43S, R4W, Sec. 24, Atwood \& Trotter 2668, 9 Jun 1971, BRY! - T43S, R4W, Sec. 33, 16 mi E of Kanab, $5200 \mathrm{ft}$, Gierisch 4380, 6 Jun 1978, ASU!, BRY! - T43S, R4W, Sec. 33, S of Hwy. 89, ca. 6 mi E of Johnson Canyon, Moenkopi Formation, in juniper-sagebrush-eriogonum community, Welsh \& $K$. Thorne 24972, 24 April 1992, BRY! - T43S, R4W, Sec. 33, dirt road turnoff after milepost 48, E of Kanab on old highway, Thorne \& Zupan 10145, 11 May 1992, BRY! - T43S, R4W, S33, S of Hwy. 89, ca. 6 mi E of Johnson Canyon, brown Moenkopi exposure, in juniper-sagebrush-eriogonum community, Welsh 25031, 29 May 1992, BRY! - T43S, R4W, Sec. 33, ca. $7 \mathrm{mi} \mathrm{E}$ of Johnson Canyon, red-brown Moenkopi Formation, juniper woods, ca. $1650 \mathrm{~m}$, Welsh 25653, 5 Jun 1993, BRY! - T43S, R3W, Sec. 4, at Telegraph Flat, Middle Red Member Moenkopi Formation, $5450 \mathrm{ft}$, Chapman s.n., 9 June 1995, BRY! - T43S, R3W, Sec. 5, at Telegraph Flat, Middle Red Member Moenkopi Formation, $5500 \mathrm{ft}$, Chapman s.n., 9 June 1995, BRY! - T43S, R3W, Sec. 22, N of Telegraph Flat, Middle Red and Schnabkaib Members Moenkopi Formation, 5600 ft, Chapman s.n., 9 June 1995, BRY! - T43S, R3W, Sec. 20, North Clay Hole Wash, Upper Red Member Moenkopi Formation, $5500 \mathrm{ft}$, Chapman s.n., 9 June 1995, BRY! - T42S, R2W, Sec. 34, just N of Hwy. 89, toe slopes around an isolated butte, Upper Red Member Moenkopi Formation, $5420 \mathrm{ft}$, Chapman s.n., 9 June 1995, BRY! - T43S, R3W, Sec. 33, Middle Red Member Moenkopi Formation, $5500 \mathrm{ft}$, Chapman s.n., 9 June 1995, BRY! - T43S, R3W, Sec. 28, $15.6 \mathrm{mi} \mathrm{E}$ of Kanab, Moenkopi Formation, 1770 m, Refsdal Dalmatier 7961, 11 June 1998, BRY! - T43S, R4W, Sec. 33, ca. 7 mi E of Johnson Canyon, $37^{\circ} 01.945^{\prime} \mathrm{N}, 112^{\circ} 14.437^{\prime} \mathrm{W}$, gypsiferous Moenkopi Formation, juniper woods, ca. $5320 \mathrm{~m}$, Welsh \& O'Dell 28056, 30 May 2001, BRY! - T43S, R3W, Sec. 11, E of Kitchen Corral Wash Road, ca. $2.5 \mathrm{mi} \mathrm{N}$ Hwy. 89, and $24.5 \mathrm{mi}$ ENE of Kanab, Moenkopi Formation, Welp \& Yarborough s.n., 16 May 2001, BRY! - T43S, R3W, Sec. 18, S of Hwy. 89, ca. 2.5 mi NE of crossing of Petrified Hollow Wash, and $4.7 \mathrm{mi} \mathrm{N}$ of Arizona state line, ca. 20 mi E of Kanab, Fertig 19934, 12 May 2002, BRY! T43S, R4W, Sec. 33, 16.5 mi E of Kanab, Hwy. 89, dirt road after milepost 48 , on road $706 \mathrm{~S}$ of highway, ca. 0.6 mi $\mathrm{E}$ to crossroads, go $\mathrm{E} 37^{\circ} 02.11^{\prime} \mathrm{N}, 112^{\circ} 14.20^{\prime} \mathrm{W}$, red rocky soil, Egan \& Egan 146, 19 Apr 2004, BRY!

Pediomelum megalanthum (Wooton \& Standley) Rydberg

ARIzona: Apache Co.-Upland near rim N of Canyon de Chelly and W of Cottonwood Canyon, on shaly Shinarump Conglomerate, common throughout the area, $5670 \mathrm{ft}$, G. Rink 211, 3 May 2001, ASC! - Navajo Reservation, $\mathrm{N}$ of Hwy. 12, ca. $4 \mathrm{mi} \mathrm{NW}$ of junction with road to Lukachukai, Chinle Formation, Reeves 8213, 15 May 1986, ASU! - W side of Lukachukai Mountains, $6 \mathrm{mi} \mathrm{E}$ of Round Rock, $36^{\circ} 31.801^{\prime} \mathrm{N}, 109^{\circ} 18.770^{\prime} \mathrm{W}$, Atwood b Clifford 27634, 5 Jun 2001, BRY! - ca. $7 \mathrm{mi}$ E of Round Rock, $36^{\circ} 30.66^{\prime} \mathrm{N}, 109^{\circ} 20.59^{\prime} \mathrm{W}$, Chinle Formation, $5772 \mathrm{ft}$, Atwood \& Clifford 34438, 5 Jun 2004, BRY! Coconino Co.-Oak Creek Canyon at Sedona, $4200 \mathrm{ft}$, Deaver 6197, 5 May 1963, ASC!, BRY!, ARIZ! - 1 mi S of Sedona, Brown 340, 7 May 1970, ARIZ! - Coconino-Yavapai area, Rt. 179, S of Sedona, just N of Bell Butte, Lehto et al. 11083, 5 May 1973, ARIZ! - Sedona, Schnebly Hill Road at Burris Lane, unbuilt lot, level red sandy soil in open clearing between shrubs, $34^{\circ} 51^{\prime} 58^{\prime \prime} \mathrm{N}, 111^{\circ} 45^{\prime} 28^{\prime \prime} \mathrm{W}, 4275$ $\mathrm{ft}$, Licher 514, 20 Apr 2003, ASC! - Sedona City, Schnebly Hill Road and Bear Wallow Lane, open level clearing in pinyon-juniper woodland on red rock, sandy soils, $34^{\circ} 37^{\prime} 0.56^{\prime \prime} \mathrm{N}, 111^{\circ} 51^{\prime} 43.0^{\prime \prime} \mathrm{W}, 4200 \mathrm{ft}$, Licher 1911, 20 Apr 2003, BRY! - Havasupai Canyon, between Havasu and Navajo falls along the trail, M. Kiser s.n., 13 Jun 1965, ASC! Yavapai Co.-Collected from a wash that drains the top of the limestone "Mesa," just off the Bill Gray Road, 8 mi NNW of the junction of the Bill Gray Road (Forest Road 761 and Hwy. 89A), $4300 \mathrm{ft}$, Sehaaek \& Morefield 1338, 20 Sep 1984, ASC! - Hartwell Canyon, TNC property, sandy soils near was edge in pinyon-juniper 
woodland, $34^{\circ} 55^{\prime} 17^{\prime \prime} \mathrm{N}, 111^{\circ} 54^{\prime} 28.9^{\prime \prime} \mathrm{W}, 4740 \mathrm{ft}$, Licher 1176, 4 May 2005, ASC! $-3.3 \mathrm{mi}$ W of Hwy. 279, on road to Cherry, flowers with a cream banner, dark blue violet wings and keel, Spellenberg et al. 3119, 15 May 1973, ASU!

Colorado: Delta Co.-1 specimen at BRY! Mesa Co. -15 specimens at BRY! Montezuma Co. -2 specimens at BRY! Montrose Co.-4 specimens at BRY!

New Mexico: San Juan Co.-Beclahbito area, ca. 1.25 mi N of Beclahbito Day School, Brushy Basin member of Morrison Formation, T31N, R21W, Sec. 35, $5700 \mathrm{ft}$, Clifford 1-80, 12 April 2001, BRY! - ca. $1 \mathrm{mi} \mathrm{W}$ of Beclabito and ca. $0.5 \mathrm{mi} \mathrm{N}$ of U.S. 64, Morrison Formation, $36^{\circ} 51^{\prime} 16^{\prime \prime} \mathrm{N}, 109^{\circ} 01^{\prime} 57^{\prime \prime} \mathrm{W}$, Heil et al. 23632,18 May 2004 , BRY! - ca. $1.75 \mathrm{mi} \mathrm{NE}$ of Blue Hill, eroded formation, first major terrace mesa below the Upper Mesa Verde Slope, T32N, R17W, Sec. 30, Point Lookout Sandstone, $5970 \mathrm{ft}$, Clifford 01-220, 5 May 2001, BRY!

Utah: Duchesne Co.-3 specimens BRY! Grand Co.14 specimens at BRY! San Juan Co._-21 specimens at BRY! Uintah Co. -37 specimens at BRY! Wayne Co.-2 specimens at BRY!

\section{Pediomelum mephiticum (S. Watson) Rydberg}

ARIzona: Mohave Co.-20 mi N of Wikieup, Arizona, Crooks \& Darrow s.n., 20 Apr 1938, ARIZ! - Wolf Hole, juniper belt, $5000 \mathrm{ft}$, Cottam 8734, 15 Jun 1941, ARIZ! Robinson Tank, Arizona Strip, Michaels 2154, 4 May 1960, ARIZ! - Pocum Wash, ca. $18 \mathrm{mi} \mathrm{W}$ of Wolf Hole, near Cane Spring, Mason, Gilbertson, \& Hevly 2823, 8 Jun 1968, ARIZ! - Wolf Hole Mountain, $0.25 \mathrm{mi}$ W of Mokiah Pass, 2.5 mi S of St. George, T40N, R12W, Sec. 33, 5000 $\mathrm{ft}$, petals pale green yellow and tipped with blue, Holmgren 3290, 22 May 1969, BRY! - Perennial, one flowering plant on sandy soil along main east-west road between Wolf Hole and Cottonwood Wash, near Mud Springs, ca. T38N, R14W, Sec. 29, Mason \& Phillips 2881, 18 Jun 1969, ARIZ! - Seegmiller Mountain Conservation Area, $0.25 \mathrm{mi} \mathrm{W}$ of road to Toroweap Valley, Matthews 94, 2 May 1970, BRY! - Black Rock Gulch S of St. George, gravelly soil, pinyon-juniper community, Higgins \& Atwood 5328, 18 May 1972, ASC!, ASU!, BRY! - E base of Black Rock Mountain, Atwood \& Higgins 5093, 18 May 1972, BRY! - T39N, R12W, Sec. 11, 15 mi S of Utah-Arizona line and $2 \mathrm{mi}$ SW of Seegmiller Mountain, Atwood 9177, 14 May 1983, BRY! - T38N, R14W, Hidden Valley S of Black Rock Mountain, 34,500 ft, Atwood 9597, 3 May 1984, BRY! - T39N, R12W, Sec. 2, ca. 17 road miles S of St. George, $5000 \mathrm{ft}$, Neese \& Cronquist 16864, 11 May 1985, BRY! - Jump Canyon SE of Black Rock Mountain, T37N, R13W, Sec. 16, Atwood 10984, 15 May 1985, BRY! - T38N, R12W, Sec. 20, ca. 30 road miles S of St. George, $5000 \mathrm{ft}$, Neese \& Cronquist 16872, 12 May 1985, BRY! Between Wolf Hole and Seegmiller Mountains, $16 \mathrm{mi}$ by road to Mount Trumbull Village, S of Arizona-Utah border, then W $0.1 \mathrm{mi}$ by Wolf Hole Mountain Road, $5040 \mathrm{ft}$, T40N, R12W, Sec. 34, Reichenbacher 1726, 19 May 1985, ARIZ! - T39N, R13W, Sec. 16, Maple Canyon, ca. $1 \mathrm{mi} \mathrm{N}$ of Little Wolf Pass, $5000 \mathrm{ft}$, Baird 3080, 18 May 1989, BRY! - W of Seegmiller Mountain, on road to Mt. Trumbull, Higgins 19018, 30 Apr 1994, BRY! - Arizona Strip, $17 \mathrm{mi}$ due SE of Littlefield, T38N, R14W, Sec. $26,1.5 \mathrm{mi}$ SE of Mud Mountain, 1224 m, Atwood \& Welsh 21816, 25 Apr 1997, BRY! - T39N, R12W, Sec. 17, just SW of Seegmiller Mountain, $5000 \mathrm{ft}$, Higgins 19578, 26 May 1998, BRY! - T39N, R13W, Sec. 10, Black Rock Gulch, 1500 m,
Higgins 21315, 15 May 2000, BRY! - T39N, R12W, Sec. 11-14, N end of Wolf Hole Valley, $1600 \mathrm{~m}$, Higgins 22896 , 11 May 2001, BRY! - T39N, R12W, Sec. 26, Wolf Hole Valley, mixed shrub, $1540 \mathrm{~m}$, Higgins et al. 20278, 27 May 1999, BRY! - T37N, R14W, Sec. 27, 2 mi N of Hidden Canyon/Wolf Hole junction, on Wolf Hole road, Atwood 25598, 11 May 2000, BRY! - T37N, R13W, Sec. 15, junction of Tweedie Hollow/Hobble roads, Atwood 25622, 11 May 2000, BRY! - T40N, R13W, Sec. 35, Black Rock Gulch, upper portion, Higgins 22848, 10 May 2001, BRY! - Black Rock Gulch, T40N, R13W, Sec. 35, 1450 m, Higgins 2248, 10 May 2001, ASU! - $13.6 \mathrm{mi} \mathrm{S}$ of I-15 on Black Rock Road, T40N, R13W, Sec. 14, Atwood 27483, 22 May 2001, BRY! - Seegmiller Mountain, T40N, R11W, Sec. 20, 1771 m, Higgins 24656, 11 Jun 2003, BRY! - Little Wolf Hole Pass, T38N, R13W, Sec. 21, 1597 m, Higgins 25642, 28 May 2004, BRY! - Quail Hill, T40N, R12W, Sec. 34, 1675 m, Higgins 26482, 23 Apr 2005, BRY! pinyon-juniper woodland, $17.71 \mathrm{mi}$ SE of Littlefield, $36^{\circ} 41^{\prime} 19^{\prime \prime} \mathrm{N}, 113^{\circ} 44^{\prime} 43^{\prime \prime} \mathrm{W}, 4120 \mathrm{ft}$, Stevens 629, $2 \mathrm{Jul}$ 2000, ASC! - Seegmiller Mountain, T40N, R11W, Sec. 20, sandy limestone soil, pinyon-juniper-sagebrush community, 1771 m, Higgins 24656, 11 Jun 2003, ASC! - $16.1 \mathrm{mi}$ $\mathrm{S}$ of Utah-Arizona state line on Hwy. 64, or $2.7 \mathrm{mi} \mathrm{S}$ of Mokiac Pass, W side of Seegmiller Mountain, T39N, R12W, Sec. 11, Coombs \& Bundy 2498, 9 Jun 1978, ASU!, BRY!, ARIZ! - ca. $5 \mathrm{mi} \mathrm{N}$ of Cane Springs, T18N, R13W, Sec. 5, $2900 \mathrm{ft}$, Butterwick/Hillyard 4639, 19 Apr 1979, ASU! - E base of Wolf Hole Mountain, vicinity of Wolf Hole Spring, 5200 ft, T39 N, R12W, Sec. 21, Brown d Parfitt 738, 20 May 1978, ASU!

Nevada: Clark Co.-T22N, R56E, Sec. 7, ca. 17 mi SE Pahrump, Charleston Mountains, $3400 \mathrm{ft}$, Thorne \& Atwood 4354, 14 Apr 1986, BRY!

Pediomelum palmeri (Ockendon) Grimes

Arizona: Santa Cruz Co.-Growing under Quercus sp., on south side of Penasco, about 0.5 miles up from junction with Sycamore Canyon. Previously known in Arizona from a single collection in Peci Canyon. Flowers red brown. Sycamore Canyon, Pajarito Mountains, Toplin b Kaiser \#029, 28 August 1978, ARIZ!

Pediomelum pauperitense S.L. Welsh, M. Licher, \& N.D. Atwood

Specimens cited following original description.

Pediomelum pentaphyllum (L.) Rydberg

ARIzona: Cochise Co.-Hwy. 181, near Chiracahua National Monument, SE of Wilcox, Deaver 6574, 1 Sep 1963, ASU! - Sunizona, from junction of Rt. 181 and Rt. 191, S $1.5 \mathrm{mi}$ along 191, then E $0.5 \mathrm{mi}$ to base of hill, grassland, silt, sandy clay, T18S, R26E, Sec. 22, McGill 6082, 9 Apr 1995, ASC!, ASU! - Sulfur Spring Valley, Sunizona, from junction of Rt. 181 and Rt. 191, $1.5 \mathrm{mi} \mathrm{S}$, then 0.5-1 mi E, T18S, R26E, Sec. 22/15, McGill 6042, 1 Apr 1995, ASU! - Sulphur Springs Valley, ca. 3 miles SW of Sunizona, 1.5 miles S of Hwy. 89/91 junction, then 0.5 miles E of Rainbows End Road, N side of 4533' Hill, sandy loam, ca. 25 plants along dirt road, T18S, R26E, Sec. 15, Anderson 2006-7, 30 Aug 2006, ARIZ! Graham Co.--Near lower San Simon plot, $3000 \mathrm{ft}$, Anderson b Rhinehart 953, 1 Apr 1936, ARIZ! 
Pediomelum retrorsum Rydberg

ARIZona: Coconino Co.-near Fredonia, T41N, R1W, Sec. 28, Gierisch 4321, 16 May 1978, ASC!, ASU! - Hwy. 66, halfway between Ashfork and Seligman, $5000 \mathrm{ft}$, Miranda b Deaver 5734, 26 May 1960, ASC! - near Fredonia, T41N, R1W, Sec. 28, Gierisch 4321, 16 May 1978, BRY! - along Winter Road, $1.3 \mathrm{mi}$ NE of junction with Hwy. 89A, T41N, R1W, Sec. 28, Brown et al. 649, 16 May 1978, BRY! - 7 mi E of Fredonia, 0.2 mi NE of Hwy. 89A, on Winter Road, red soil, big sage grassland, Lehto L23765, 19 May 1979, ASU! - $7 \mathrm{mi} \mathrm{E}$ of Fredonia, $0.2 \mathrm{mi}$ NE of Hwy. 89A, on Winter Road, red soil, big sage grassland, Lehto L23770, 19 May 1979, ASU! - $7.7 \mathrm{mi}$ E of Fredonia, opposite road oil storage tank, T41N, R1W, Sec. 33, Lehto L23857, 21 May 1979, ASU! - Upper Little Robinson Canyon, ca. $2.0 \mathrm{mi} \mathrm{SE}$ of Twin Tanks, $5400 \mathrm{ft}, \mathrm{T} 36 \mathrm{~N}$, R5W, Sec. 20, Brown \& Parfitt s.n., 18 May 1978, ASU! Robinson Tank, Arizona Strip, collector unknown, 4 May 1960, ASU! - Winter Road, $0.7 \mathrm{mi}$ NE of U.S. 89A, $7 \mathrm{mi}$ SE of Fredonia, T41N, R1W, Sec. 28, $4900 \mathrm{ft}$, with fungal rust, Phillips et al. 78-593, 13 Jun 1978, ASU! - ca. 2 mi W of Wolf Hole on road to Wolf Hole, ca. $5000 \mathrm{ft}, \mathrm{T} 39 \mathrm{~N}$, R12W, Sec. 22, Brown et al. 871, 24 May 1978, ASU! Winter Road, T41N, R1W, Sec. 28, Hughes 03, 04, 26 Apr 1989, both BRY!, Hughes 01, 02, both ARIZ! - ca. $6.6 \mathrm{mi}$ ESE Fredonia, Hwy. 89A, then $1.2 \mathrm{mi} \mathrm{NE}$ on Rd. 1025, just $\mathrm{E}$ of power lines, $36^{\circ} 55.11^{\prime} \mathrm{N}, 112^{\circ} 24.68^{\prime} \mathrm{W}, \mathrm{T} 41 \mathrm{~N}$, R1W, Sec. 28, 4850 ft, Egan \& Egan 145c, 19 Apr 2004, BRY! Gila Co.— $5 \mathrm{mi} \mathrm{N}$ of Coolidge Dam, Maguire et al. 10504, 5 Apr 1935, BRY!, ARIZ! - 13 mi E of Globe, 4100 ft, R.H. Peebles 14602, 18 Apr 1940, ARIZ! Graham Co.-20 mi E of Globe on rolling hills, Atwood 2244, 29 Mar 1970, BRY! Graham or Greenlee Co.?-SaffordClifton area, Gila Project, D.C. Craig s.n., 29 Apr 1936 , ASU! Greenlee Co.-4 miles E of Clifton, Carney Page s.n., May 1946, ARIZ! Maricopa Co._Arizona 87, 2 miles $\mathrm{N}$ of Saguaro Lake, growing in a ravine with Yucca baccata, $2600 \mathrm{ft}$, Lehto 508, 14 Apr 1962, ASC! - Arizona 87, 2 miles $\mathrm{N}$ of Saguaro Lake, growing in a ravine with Yucca baccata, $2600 \mathrm{ft}$, Eliinor Lehto 508a, 14 Apr 1962, ASU! About $11 \mathrm{mi} \mathrm{S}$ of Sunflower on Hwy. 87, and $2.6 \mathrm{mi} \mathrm{N}$ of turnoff to Sugarloaf Mountain, W side of highway, T4N, R8E, Sec. 2, $2100 \mathrm{ft}$, Parfitt \& Bricker 3732, 28 Mar 1988, ASU! (voucher for chromosome count, $n=11$, Debbie Rickel 1988) - Beeline Hwy., 2 mi N of Saguaro Lake turnoff, Russell 1384, 2 Apr 1960, ASU! - Rock Creek (10 mi E of Saguaro Lake off Beeline Hwy., $3500 \mathrm{ft}$, Dammann 45, 16 Apr 1961, ASU! - ca. 11 mi S of Sunflower, just E of Hwy. 87, $33^{\circ} 43.781^{\prime} \mathrm{N}, 111^{\circ} 30.438^{\prime} \mathrm{W}, 2058 \mathrm{ft}$, Salywon of Wojciechowski 1058, 13 May 2001, ASU! - $25 \mathrm{mi} \mathrm{N}$ of Mesa on Beeline Hwy., B.F. Back s.n., 24 Apr 1960, ASU! - Along Beeline Highway, Dammann s.n., 15 Apr 1961, ASU! Mohave Co.-Hwy. 93 cutoff, 2 miles S of Hwy. 66 and Hackberry, 3200 ft, Deaver 6147, 16 Apr 1963, ASC! Sandy soil along road to Cottonwood Spring, T38N, R15W, Sec. 2, Mason \& Phillips 2888, 19 Jun 1969, ARIZ! - ca. 19 mi S of Virgin River bridge on Hwy. 64, along dugway, Atwood 1728, 26 May 1969, BRY! - E bajada of the Peacock Mountains, $3.5 \mathrm{mi}$ due SE of Hackberry, T23N, R13W, Sec. 32, $3900 \mathrm{ft}, N$. \& P. Holmgren 7138, 7 May 1973, BRY! - ca. 10 mi E of Fredonia sawmill along the logging road, red shale of Atriplex community, Atwood 4798, 12 May 1973, BRY! - About $3 \mathrm{mi} \mathrm{N}$ of Valentine, Hwy. 66, Gierisch 3915, 20 May 1977, ASU! - Kanab Creek Overlook Road, $1.3 \mathrm{~km}(0.8 \mathrm{mi}) \mathrm{SE}$ of Toroweap Road turnoff, $13.5 \mathrm{~km}$ (8.4 mi) S of Arizona Hwy. 38, 26 $\mathrm{km}(16 \mathrm{mi})$ due SW of Fredonia, T39N, R4W, 523, $1400 \mathrm{~m}$, N. Holmgren et al. 9150, 24 May 1979, BRY! - Near Robinson Reservoir, T36N, R5W, Sec. 21, Coombs b Bundy 2828, 12 Jun 1979, ASC!, ASU!, BRY! - along road at Little Robinson Canyon, T36N, R5W, Sec. 20, Bundy 140, 1 Jul 1980, ASU!, BRY!, ARIZ! - T26N, R11W, Sec. 28, $5 \mathrm{mi}$ N of Peach Springs Post Office, Peach Springs Canyon, $3600 \mathrm{ft}, B$. Welsh 1345, 17 May 1982, ASU!, BRY! - East bajada of the Peacock Mountains, $3.5 \mathrm{mi}$ due SE of Hackberry, T23N, R13W, Sec. 32, $3900 \mathrm{ft}, N$. \& P. Holmgren 7138, ASU! - Hwy. 93, W of Aquarius Mountains, T18N, R13W, Sec. 8, Butterwick et al. 5036, ASU! Yavapai Co.-Hills on E side of Black Mountains, W of Hwy. 93, T11N, R8W, Sec. 28, $2700 \mathrm{ft}$, basalt and andesite, Fischer 6414, 6 May 1979, ASU!, ARIZ! - Williamson Valley Road, ca. $30 \mathrm{mi} \mathrm{N}$ of Prescott and $10 \mathrm{mi} \mathrm{SW}$ of Walnut Creek, $4600 \mathrm{ft}$, McLaughlin \& Bowers 6860, 30 May 1993, ARIZ!

Nevada: Lincoln Co.-White River Valley, 5.9 mi SSE of county line on Hwy. 318 to Hiko, then WSW $0.6 \mathrm{mi}$, T2N, R62E, Sec. 3, $5100 \mathrm{ft}$, Tiehm \& Nachlinger14918, 23 May 2005, ASC!

UtaH: Washington Co.-T42S, R19W, Sec. 35, Limestone Knolls, ca. $20 \mathrm{mi}$ due W of St. George, $1200 \mathrm{~m}$, Welsh 21644, 15 Apr 1983, BRY! - T42S, R19W, Sec. 35, on a limestone knoll with red-clay slope, $1200 \mathrm{~m}$, Baird \& Franklin 464, 21 Apr 1984, BRY! - T42S, R19W, Sec. 25, $1200 \mathrm{~m}$, Limestone knoll and red-clay slope, Franklin 414, 21 Apr 1984, BRY! - T39S, R16W, Sec. 13, Gardner Ranch SE of Central, $5596 \mathrm{ft}$, Claron Formation, Warrick 1201, 12 May 1986, BRY! - T39S, R16W, Sec. 8, ca. 3 mi $\mathrm{W}$ of Central, $4800 \mathrm{ft}$, Welsh \& Franklin 23963, 24 Apr. 1988, BRY - T43S, R13W, Sec. 13, ca. 9 mi due S of Hurricane, $\mathrm{E}$ of fault, ca. $1 \mathrm{mi} \mathrm{S}$ of The Divide, on Moenkopi Formation, Welsh 24020, 9 May 1988, BRY!

Pediomelum verdiense S.L. Welsh \& M. Licher

Specimens cited following original description. 